\title{
Projection of the demand for energy sources by car fleet in Poland by the year 2030
}

\begin{abstract}
The paper presents an expert assessment of the number of passenger cars and light trucks (with a maximum mass not exceeding $3.5 \mathrm{Mg}$ ), trucks (with a maximum mass exceeding $3.5 \mathrm{Mg}$ ) and buses for 2010 and forecast up to the 2030 taking into account types of energy sources (petrol, diesel fuel, liquefied petroleum gas, natural gas and electricity). The average annual mileage and average operational consumption of energy sources have been estimated. On this basis, the projected energy sources consumption for the years 2010, 2015, 2020, 2025 and 2030 has been defined.
\end{abstract}

Key words: car transport, cars, annual mileage, fuel consumption

\section{Prognoza popytu na nośniki energii przez park samochodowy w Polsce w perspektywie 2030 r.}

W opracowaniu przedstawiono eksperckie oszacowanie liczby samochodów osobowych, lekkich samochodów ciężarowych (o masie maksymalnej nie przekraczajacej 3,5 Mg), samochodów ciężarowych (o masie maksymalnej przekraczającej 3,5 Mg) i autobusów dla 2010 r. i prognozę do 2030 r. z uwzględnienie rodzajów nośników energii (benzyna, olej napędowy, skroplony gaz ropopochodny, gaz ziemny i energia elektryczna). Oszacowano średnie roczne przebiegi oraz średnie eksploatacyjne zużycie nośników energii. Na tej podstawie wyznaczono dla lat 2010, 2015, 2020, 2025 i 2030 przewidywane zużycie nośników energii.

Słowa kluczowe: transport samochodowy, samochody, przebiegi roczne, zużycie paliwa

\section{Introduction}

The scope of the published forecast of the demand for energy sources by the Polish cars fleet applies to the following groups of vehicles [10]:

a) passenger cars - category M1,

b) light trucks (i.e. vans) with a maximum mass not exceeding $3.5 \mathrm{Mg}$ - category $\mathrm{N} 1$,

c) buses - category M2 and M3,

d) trucks with a maximum mass exceeding $3.5 \mathrm{Mg}$ - Category N2 and N3.

Forecast of the consumption of energy sources was developed using the method proposed by ITS and approved by the Department of Transport Policy and International Affairs of the Ministry of Transport, Construction and Maritime Economy in 2011 [12]. This method requires that the three main factors that determine the level of demand for energy sources in various categories of vehicles:

a) estimates the number of vehicles $-\mathrm{N}$,

b) estimates of average annual vehicles' mileages $-\mathrm{P}$,

c) estimates of average operational energy sources consumption (per $100 \mathrm{~km}$ of vehicles mileage) - Q.

Energy sources consumption represents the sum, for the individual vehicle categories, of the multiplication products of the number of vehicles, their mileages and the operational fuel consumption.

$$
\mathrm{G}=\mathrm{c} \cdot \sum_{\mathrm{i}=1}^{\mathrm{K}} \mathrm{N}_{\mathrm{i}} \cdot \mathrm{P} \cdot \mathrm{Q}_{\mathrm{i}}
$$

where $\mathrm{K}$ - the number of vehicles category, $\mathrm{c}-$ constant depending on the measurement units used.

\section{Wstęp}

Zakres prezentowanej prognozy popytu na nośniki energii przez polski park samochodowy dotyczy następujących grup pojazdów [10]:

a) samochodów osobowych - kategoria M1,

b) lekkich samochodów ciężarowych (tzw. dostawczych) o masie maksymalnej nie przekraczającej 3,5 Mg - kategoria N1,

c) autobusy - kategoria M2 i M3,

d) samochody ciężarowe o masie maksymalnej przekraczającej 3,5 Mg - kategoria N2 i N3.

Prognozę zużycia nośników energii opracowano przy wykorzystaniu metody zaproponowanej przez ITS i przyjętej przez Departament Polityki Transportowej i Spraw Międzynarodowych Ministerstwa Transportu, Budownictwa i Gospodarki Morskiej w 2011 r. [12]. Metoda ta wymaga uwzględnienia trzech zasadniczych czynników decydujących o wielkości popytu na nośniki energii w poszczególnych kategoriach pojazdów:

a) prognozy liczb pojazdów - N,

b) prognozy średnich rocznych przebiegów pojazdów - P,

c) prognozy średniego eksploatacyjnego zużycia nośników energii (przypadającego na $100 \mathrm{~km}$ przebiegu pojazdów) - Q.

Zużycie nośników energii jest sumą dla poszczególnych kategorii pojazdów iloczynów liczb pojazdów, ich przebiegu i eksploatacyjnego zużycia paliwa - wzór (1),

gdzie: K - liczba kategorii pojazdów, c - stała zależna od użytych jednostek miar.

W przedstawionej prognozie zaprezentowano jeden wariant prognozy, uznany przy obecnym stanie wiedzy ekspertów, za najbardziej prawdopodobny $[2,3,11]$. 
The forecast presented shows one projection variant considered, at the current state of knowledge of experts, as the most likely $[2,3,11]$.

\section{Forecast of the number of car fleet in Poland by the 2030}

As of the situation at the end of 2010, the number of registered passenger cars in Poland amounted to 17,239.8 thousand [7]. It is estimated that the individual transport means (mostly passenger cars) accounted for 280 billion passenger-kilometres of transport work conducted in that year. [2]

The share of passenger cars in the structure of the transport work for the different types and modes of transport is dominant now and will be in the next twenty years [2].

Forecast of the total number of passenger cars in Poland by the 2030 [3] indicates that this number in the years 2010 to 2030 is expected to rise from 17.2 million to (20.5-22.7) million.

Analysis of trends and determinants of the fuel development for passenger car leads to the conclusion that in Poland, by the 2030 a further increase in the number of cars in operation will primarily be based on cars powered by internal combustion engines.

Currently, in the structure of fuel types of the passenger cars registered in the country, still dominates gasoline. In 2010 , passenger cars with petrol engines accounted for about $62 \%$ of the structure of the fleet, and cars with engines running on diesel fuel, about $23 \%$. In the recent years, the dynamic growth in the number and share in the structure of passenger cars fleet in Poland has been of the vehicles powered by diesel engines. For example, this share in 2005 was about $9 \%$ [12], and by the end of 2011 it increased to approximately $25 \%$ [7].

According to expert forecasts, after 2025, the interest in the purchase of cars with engines fuelled by diesel fuel, due to their technical complexity and rising prices may decline in Poland. In the years 2025-2030 it is assumed that the number of registered in Poland passenger cars with diesel engines will decline as well as the decrease in their share in the fuel structure of all the cars in Poland, will take place.

Poland has one of the leading places in the world in terms of the number of cars with engines fuelled by liquefied petroleum gas (LPG). By the end of 2010, the number of passenger cars with LPG systems in Poland amounted to 2,477.6 thousand and at the end of 2011 amounted to 2,615.3 thousand [7]. The reason for the development of LPG in Poland are, in many cases, lower operating costs of cars equipped with dual fuel supply system when compared to the cost of cars with petrol engines. Not without significance is the fact of a dense network of LPG fuel stations in Poland.

One factor that may affect the decline in interest of operating cars fitted with LPG systems may be, in the forecast years, the increase in prices of LPG fuel in relation to the prices of petrol and diesel fuel. One should be aware that over the LPG industry in Poland and throughout the European Union hangs threat of losing preferential rate

\section{Prognoza liczebności parku samochodowego w Polsce do 2030 r.}

Wg stanu na koniec 2010 r., liczba zarejestrowanych w Polsce samochodów osobowych wyniosła 17239,8 tys. szt. [7]. Szacuje się, że środkami motoryzacji indywidualnej (głównie samochodami osobowymi) wykonano w tymże roku pracę przewozową rzędu $280 \mathrm{mld}$ pasażerokilometrów [2].

Udział samochodów osobowych w strukturze pracy przewozowej przy różnych rodzajów i gałęzi transportu jest obecnie oraz będzie w perspektywie najbliższych dwudziestu lat dominujący [2]. Prognoza ogólnej liczby samochodów osobowych w Polsce do 2030 r. [3] wskazuje, że liczba ta w latach $2010-2030$ powinna wzrosnąć z 17,2 mln szt. do $(20,5-22,7) \mathrm{mln}$ szt.

Analiza trendów i uwarunkowań rozwoju paliwowego samochodów osobowych prowadzi do wniosku, że w Polsce w perspektywie roku 2030 dalszy wzrost liczby eksploatowanych samochodów bazował będzie przede wszystkim na samochodach napędzanych silnikami spalinowymi.

Aktualnie w strukturze rodzajów paliw samochodów osobowych zarejestrowanych w kraju dominuje benzyna. W 2010 r. samochody osobowe z silnikami benzynowymi stanowiły około $62 \% \mathrm{w}$ strukturze parku, a samochody z silnikami zasilanymi olejem napędowym około $23 \%$. W ostatnich latach obserwowano dynamiczny wzrost liczby i udziału w strukturze parku samochodów osobowych w Polsce pojazdów z silnikami zasilanymi olejem napędowym. Przykładowo udział ten wynosił w 2005 r. około $9 \%$ [12], a wg stanu na koniec $2011 \mathrm{r}$ wzrósł do około $25 \%$ [7].

Wg eksperckich przewidywań, po roku 2025 zainteresowanie zakupem samochodów osobowych z silnikami zasilanymi olejem napędowym, z powodu ich technicznego skomplikowania i rosnącej ceny może w Polsce maleć. W latach 2025-2030 zakłada się spadek zarejestrowanych w Polsce samochodów osobowych z silnikami na olej napędowy oraz spadek ich udziału w strukturze paliwowej wszystkich samochodów osobowych w Polsce.

Polska zajmuje jedno z czołowych miejsc w świecie pod względem liczby samochodów z silnikami zasilanymi skroplonym gazem ropopochodnym LPG (Liquefied Petroleum Gas). Wg stanu na koniec 2010 r. liczba samochodów osobowych z instalacjami LPG w Polsce wynosiła 2477,6 tys. szt., a na koniec 2011 r. wynosiła 2615,3 tys. szt. [7]. Przyczyną rozwoju LPG w Polsce są w wielu przypadkach niższe koszty eksploatacji samochodów wyposażonych w dwupaliwowy system zasilania w porównaniu z kosztami samochodów z silnikami benzynowymi. Nie bez znaczenia jest fakt gęstej sieci stacji zasilania paliwem LPG w Polsce.

Czynnikiem, który może wpłynąć na spadek zainteresowania eksploatacją samochodów wyposażonych w instalacje LPG może być w latach prognozy wzrost cen paliwa LPG w relacji z cenami benzyny i oleju napędowego. Trzeba mieć świadomość, że nad branżą LPG w Polsce i w całej Unii Europejskiej wisi groźba utraty preferencyjnej stawki akcyzowej. W projekcie nowej dyrektywy w tej kwestii Komisja Europejska proponuje rozwiązania, które mogą 
of excise duty. In the new draft directive on this issue, the European Commission proposes solutions that can make the use of LPG for vehicles completely unaffordable. This project was widely protested and probably in this form will not enter into force. However, the industry needs to prepare for a compromise solution that will still probably be worse than the status quo. It is not therefore inconceivable that, due to the high taxation of this fuel, a good period of LPG in Poland may come to an end.

Number of passenger cars with engines powered by natural gas: compressed ( $\mathrm{CNG}$ - Compressed Natural Gas) and liquefied (LNG - Liquefied Natural Gas) in a car fleet in Poland is insignificant. According to the data from the CEP 2009 database, this number stood at 1,915 representing $0.01 \%$ of the passenger cars fleet registered in Poland [4].

The main barrier to the development of the use of natural gas in road transport in Poland is a small number of public gas distribution stations and the relatively high costs of adapting the car to run on this fuel. Another limiting factor in the decisions of potential users of cars powered by natural gas is uncertainty as to the competitive price of this fuel remaining, in comparison with the prices of other fuels used in cars. The Excise Tax Act of 28 December 2008 has a zero rate set a of excise duty on natural gas, which will be valid until 31 October 2013.

It may be expected that in the years of the forecast there will be a certain development of the use of natural gas to power the car engines. It will be dependent on the future relationship between the prices of natural gas and gasoline, diesel fuel and LPG.

High prices of conventional fuels (petrol and diesel fuel) resulting mainly from crude oil prices on the world market and the EU's policy aiming to reduce the growth of greenhouse gas emissions (mainly carbon dioxide) will affect the stimulation of the development of the natural gas market in the EU, including the Poland.

The scale of the development of electric vehicles in Poland is now marginal, despite these cars currently already available on the market. It is estimated that in 2011 Poland had registered few dozens of electric cars. One should not expect, in the next few years, a spontaneous expansion of electric cars in Poland.

The legitimacy of promoting the development of electric vehicles use depends on the source of electricity that will be supplied to the batteries of these vehicles. As long it is made mostly from solid fuels (fossil), as is the case in Poland the indirect greenhouse gas emission of electric vehicles is greater than the emission generated by modern internal combustion engines $[1,6]$. However, an argument for electric vehicles is zero emissions of air polluting gases in the traffic lane, including in urban areas. Thus, from the point of view of greenhouse gas emissions electric vehicle system development will have a justification following the change in the structure of energy sources in Poland.

From the point of view of the average electric cars operating costs, even with rough estimates of the expected prices of motor fuels (gasoline and diesel fuel), it is rather difficult spowodować, że stosowanie LPG do napędu pojazdów stanie się całkowicie nieopłacalne. Projekt ten został jednak szeroko oprotestowany i zapewne w tym kształcie nie wejdzie w życie. Branża musi jednak przygotować się na rozwiązanie kompromisowe, które i tak zapewne okaże się gorsze od stanu obecnego. Nie jest zatem wykluczone, że dobry okres LPG w Polsce z powodu wysokiego opodatkowania tego paliwa podatkiem akcyzowym może dobiec końca.

Liczba samochodów osobowych z silnikami zasilanymi gazem ziemnym: sprężonym (CNG - Compressed Natural Gas) i skroplonym (LNG - Liquefied Natural Gas) w strukturze parku samochodów osobowych w Polsce jest niewielka. Wg danych z bazy danych CEP 2009 r. liczba ta wyniosła 1915 szt., co stanowiło 0,01 \% parku samochodów osobowych zarejestrowanych w Polsce [4].

Główną barierą rozwoju wykorzystania gazu ziemnego w transporcie samochodowym w Polsce jest mała liczba publicznych stacji dystrybucji gazu oraz stosunkowo wysokie koszty przystosowania samochodów do zasilania tym paliwem. Dodatkowym czynnikiem ograniczającym decyzje potencjalnych użytkowników samochodów osobowych zasilanych gazem ziemnym jest niepewność co do utrzymania się konkurencyjnej ceny tego paliwa w porównaniu z cenami innych paliw stosowanych w samochodach. W ustawie o podatku akcyzowym z dnia 28 grudnia 2008 r. określono zerową stawkę podatku akcyzowego od gazu ziemnego, która będzie obowiązywać do 31 października 2013 r.

Można oczekiwać, że w Polsce w latach objętych prognozą nastąpi pewien rozwój wykorzystania gazu ziemnego do zasilania silników samochodowych. Będzie on uwarunkowany przyszłymi relacjami pomiędzy cenami gazu ziemnego oraz benzyny, oleju napędowego i LPG.

Wysokie ceny tradycyjnych paliw (benzyny i oleju napędowego) wynikające głównie $\mathrm{z}$ cen ropy naftowej na światowym rynku oraz polityka UE zmierzająca do ograniczenia dynamiki wzrostu emisji gazów cieplarnianych (przede wszystkim dwutlenku węgla) będą wpływały na stymulowanie rozwoju rynku gazu ziemnego w UE, w tym w Polsce.

Skala rozwoju w Polsce samochodów elektrycznych jest obecnie w Polsce marginalna, pomimo aktualnie już dostępnych na rynku samochodów z tym napędem. Szacuje się, że w 2011 r. w Polsce było zarejestrowanych kilkadziesiąt elektrycznych samochodów osobowych. Nie należy oczekiwać w najbliższych latach żywiołowego rozwoju ilościowego samochodów elektrycznych w naszym kraju.

Zasadność promowania rozwoju stosowania pojazdów elektrycznych zależy od źródeł energii elektrycznej, którą zasilane będą akumulatory tych pojazdów. Jak długo produkowana jest ona głównie z paliw stałych (kopalnych), jak to ma miejsce w Polsce, ciągniona emisja gazów cieplarnianych z samochodów z napędem elektrycznym jest większa niż emisja generowana przez nowoczesne silniki spalinowe [1, 6]. Natomiast argumentem przemawiającym na rzecz pojazdów z napędem elektrycznym jest zerowa emisja gazów zanieczyszczających powietrze w pasie drogowym, w tym w obszarach zabudowanych. Zatem z punktu widzenia emisji 
to expect in the medium term, the economic competitiveness of electric cars with the internal combustion engines equipped ones.

Electric cars, mainly because of their limited range, are now seen by their potential users as "uncertain" means of transportation. Technical progress in the construction of the batteries gradually affects the increase in their range, however it is too early to talk, at this point, about the operational competitiveness of electric vehicles to vehicles with conventional engines. Experience shows that such vehicles in the future will be primarily used for local journeys, such as in urban areas $[1,6]$. The electric car will usually be second or a third car in the family of a high financial status.

According to the projections over the forecast period, in Poland will continue to dominate cars equipped with gasoline engines, while their share in total passenger car fleet will be around $56 \%$ in 2020 and around $55 \%$ in 2030 (in 2010 was at about $62 \%$ ).

Cars equipped with diesel fuel powered engines should be around $28 \%$ in 2020 and around $26 \%$ in 2030 (in 2010, about $23 \%$ ) of the total passenger car engines. In the forecast years, the share of cars with engines running on liquefied petroleum gas is expected to be $16 \%$ (in 2010 about $15 \%$ ). It is expected that in 2030 the share of passenger cars with engines fuelled by natural gas in the total number of cars in Poland will amount to about $2.5 \%$, and the share of electric vehicles will account for around $0.1 \%$.

Figure 1 shows the forecast number of passenger cars in Poland by the 2030 acc. to the type of energy sources.

Projected numbers of trucks by maximum mass groups are subject first of all to the projected haulage work of the Polish fleet of trucks and the projected average haulage work productivity of the statistical transport vehicle.

Anticipating change in the average annual haulage work productivity of the statistical truck during the forecast period it is assumed that the technical - operational indicators,

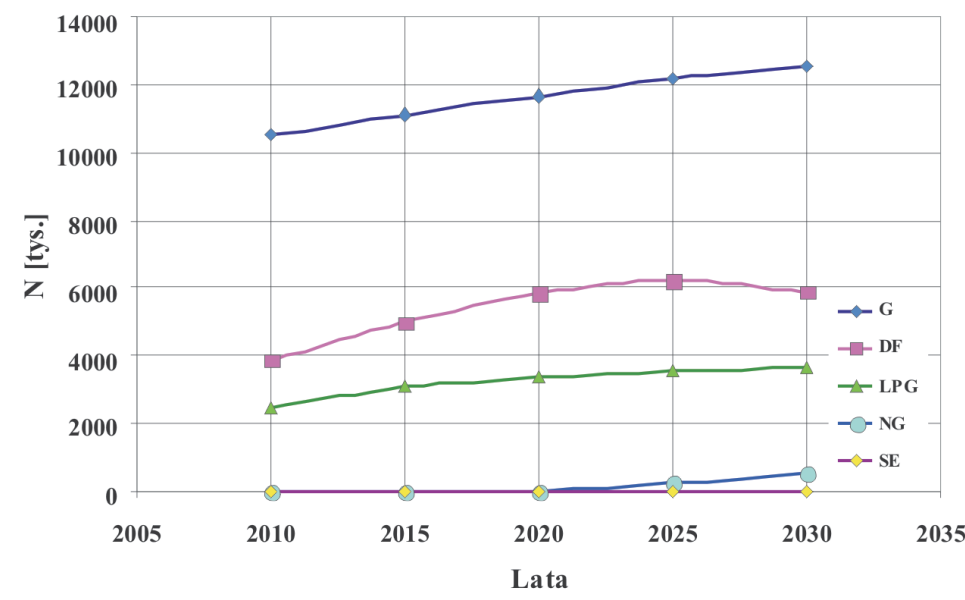

Fig. 1. Forecast numbers of passenger cars arranged by type of energy sources: G - gasoline, DF - diesel fuel, LPG - liquefied petroleum gas, NG - natural gas, SE - electricity

Rys. 1. Prognoza liczb samochodów osobowych wg rodzajów nośników energii:

$G$ - benzyna silnikowa, DF - olej napędowy, $L P G$ - skroplony gaz ropopochodny, $N G$ - gaz ziemny, SE - energia elektryczna gazów cieplarnianych rozwój systemu pojazdów elektrycznych będzie miał uzasadnienie po zmianie struktury źródeł energii elektrycznej w Polsce.

Z punktu widzenia średnich kosztów eksploatacji samochodów elektrycznych, nawet przy zgrubnych oszacowaniach dotyczących przewidywanych cen paliw silnikowych (benzyny i oleju napędowego), raczej trudno oczekiwać w perspektywie średniookresowej, ekonomicznej konkurencyjności stosowania samochodów elektrycznych w stosunku do wyposażonych w silniki spalinowe.

Samochody elektryczne, przede wszystkim z uwagi na ich ograniczony zasięg, postrzegane są obecnie przez potencjalnych ich użytkowników jako „niepewny” środek lokomocji. Postęp techniczny w konstruowaniu akumulatorów wpływa stopniowo na zwiększanie ich zasięgu, jednak za wcześnie mówić w tej chwili o konkurencyjności eksploatacyjnej samochodów elektrycznych wobec pojazdów z konwencjonalnymi silnikami. Z dotychczasowych doświadczeń wynika, że samochody takie będą w przyszłości wykorzystywane przede wszystkim do jazd lokalnych np. na obszarze miast $[1,6]$. Samochód elektryczny będzie najczęściej drugim albo trzecim samochodem $\mathrm{w}$ rodzinie o wysokim statusie finansowym.

Wg przewidywań w okresie objętym prognozą w Polsce nadal będą dominowały samochody osobowe wyposażone $\mathrm{w}$ silniki benzynowe, przy czym ich udział w strukturze parku samochodów osobowych ogółem wyniesie około $56 \%$ w roku 2020 i około 55 \% w roku 2030 (w roku 2010 około $62 \%$ ).

Samochody wyposażone w silniki zasilane olejem napędowym powinny stanowić około $28 \%$ w 2020 r. i około 26 \% w 2030 r. (w 2010 r. około 23 \%) ogółu silników samochodów osobowych. W latach prognozy przewiduje się udział samochodów osobowych z silnikami na skroplony gaz ropopochodny rzędu 16 \% (w 2010 r. około 15 \%). Przewiduje się, że w roku 2030 udział samochodów osobowych wyposażonych w silniki zasilane gazem ziemnym wśród ogółu samochodów w Polsce wyniesie około $2,5 \%$, a udział samochodów elektrycznych będzie stanowił około $0,1 \%$.

Na rysunku 1 przedstawiono prognozę liczb samochodów osobowych w Polsce do 2030 r. wg rodzajów nośników energii.

Prognozowane liczby samochodów ciężarowych wg grup masy maksymalnej są uwarunkowane przede wszystkim prognozowaną pracą przewozową polskiego parku ciężarowego i prognozowanej średniej wydajności pracy przewozowej statystycznego pojazdu.

Przewidując zmiany średniej rocznej wydajności statystycznego samochodu ciężarowego w okresie prognozy zakłada się, że cechami techniczno-eksploatacyjnymi, które w sposób szczególny będą wpływać na wzrost tej wydajności w skali dotyczącej całości polskiego transportu samochodowego będą: wzrost wykorzystania taboru, wzrost wykorzystania przebiegu, wzrost wykorzystania czasu pracy. 
which will specifically affect the growth of this productivity on the entire scale of the Polish road transport will be: an increase in the utilization of the rolling stock, mileage, and operating time. Formation of these indicators will be enhanced by the anticipated structural changes in the Polish freight transport, which affect, among others modernization of the structure of the trucks fleet, changes in the structure of the size of companies in the commercial road transport and logistics development, the use of modern information and communication technologies in transport, the development of motorways and expressways, etc.

According to current estimates [3] for the period up to 2030 , the dominance of haulage work carried out by the truck fleet, will be maintained.

It is expected that in 2030 about $95 \%$ of haulage work of the entire Polish freight road transport will be performed by the fleet of above $3.5 \mathrm{Mg} \mathrm{GVW}$. The forecast, for 2030, total number of trucks in Poland should be around 3,394 thousand (Fig. 2) including the number of trucks up to 3.5 $\mathrm{Mg}$ of a maximum mass - about 2,514 thousand and those above $3.5 \mathrm{Mg}$ of a maximum mass about 880 thousand.

Projected numbers of trucks by maximum mass groups are subject first of all to the projected haulage work of the Polish fleet of trucks and the projected average haulage work productivity of the statistical transport vehicle.

Anticipating change in the average annual haulage work productivity of the statistical truck during the forecast period it is assumed that the technical - operational indicators, which will specifically affect the growth of this productivity on the entire scale of the Polish road transport will be: an increase in the utilization of the rolling stock, mileage, and operating time. Formation of these indicators will be enhanced by the anticipated structural changes in the Polish freight transport, which affect, among others modernization of the structure of the trucks fleet, changes in the structure of the size of companies in the commercial road transport and logistics development, the use of modern information and communication technologies in transport, the development of motorways and expressways, etc.

According to current estimates [3] for the period up to 2030 , the dominance of haulage work carried out by the truck fleet, will be maintained.

It is expected that in 2030 about $95 \%$ of haulage work of the entire Polish freight road transport will be performed by the fleet of above $3.5 \mathrm{Mg}$ of a maximum mass. The forecast, for 2030, total number of trucks in Poland should be around 3,394 thousand (Fig. 2) including the number of trucks up to $3.5 \mathrm{Mg}$ of a maximum mass - about 2,514 thousand and those above $3.5 \mathrm{Mg}$ of a maximum mass - about 880 thousand.

Compared to the overall truck fleet in 2010 , the projected growth of the fleet by the 2030 would be around $14 \%$. Compared to the truck fleet with a maximum mass of more
Kształtowaniu się tych wskaźników powinny sprzyjać przewidywane zmiany strukturalne w polskim transporcie ciężarowym, wpływające m.in. na unowocześnienie struktury parku ciężarowego, zmiany struktury wielkości przedsiębiorstw w zarobkowego transportu samochodowego, a także rozwój logistyki, wykorzystanie nowoczesnych metod informacyjno-komunikacyjnych w transporcie, rozwój sieci autostrad i dróg ekspresowych itp.

Wg aktualnej prognozy [3] w okresie do 2030 r. będzie utrzymana dominacja pracy przewozowej wykonywanej ciężkim taborem ciężarowym. W 2030 r. około $95 \%$ pracy przewozowej całego polskiego ciężarowego transportu samochodowego wykonywane będzie taborem o masie maksymalnej większej niż 3,5 Mg. Prognozowana na 2030 r. liczba ogółem samochodów ciężarowych w Polsce powinna wynieść około 3390 tys. szt. (rys. 2), w tym liczba samochodów ciężarowych o masie maksymalnej mniejszej niż 3,5 Mg - około 2510 tys. szt., a o masie maksymalnej większej niż 3,5 Mg - około 880 tys. szt.

Fig. 2. Forecast of the numbers of trucks acc. to the maximum mass groups $-\mathrm{mm}$ Rys. 2. Prognoza liczb samochodów ciężarowych wg grup masy maksymalnej-mm

W porównaniu do stanu ogółem parku ciężarowego w 2010 r. prognozowany wzrost liczby parku do 2030 r. wyniósłby około $14 \%$. W porównaniu do stanu taboru ciężarowego o masie maksymalnej większej niż 3,5 Mg w $2010 \mathrm{r}$. prognozowany wzrost liczby parku wyniósłby około $9 \%$. W przypadku pojazdów o masie maksymalnej mniejszej od $3,5 \mathrm{Mg}$ zmiana ta wyniosłaby około $16 \%$.

Przewiduje się, że w roku 2030 samochody ciężarowe o masie maksymalnej mniejszej niż 3,5 Mg z silnikami o zapłonie samoczynnym stanowiły będą około $75 \%$ tego parku (około 59 \% w 2010 r.). Zakłada się utrzymanie tendencji spadku udziału samochodów z silnikami o zapłonie iskrowym w strukturze samochodów ciężarowych o masie maksymalnej mniejszej niż 3,5 Mg (rys. 3). Udział ten w 2030 r. zmaleje do około $15 \%$ (około $33 \%$ w 2010 r.). 
than $3.5 \mathrm{Mg}$ in 2010, the projected increase in the number of the trucks in the fleet would be around $9 \%$. In the case of vehicles with a maximum mass of less than $3.5 \mathrm{t}$, this change would be around $16 \%$.

It is expected that in 2030 trucks with a maximum mass of less than $3.5 \mathrm{Mg}$ with the compresion-ignition engines will account for approximately $75 \%$ of the fleet (about $59 \%$ in 2010). Expected is continuation of the declining trend in the share of vehicles with petrol engines in the structure of the trucks fleet up to $3.5 \mathrm{Mg}$ of a maximum mass (Fig. 3). It is assumed that this proportion will decrease in 2030 to about $15 \%$ (2010 - about $33 \%$ ).

Dual-fuel systems supplying truck engines will continue to develop (petrol + LPG), although the dynamics of change in this area will be lower than in the first decade of the twenty-first century. It is expected that in 2030, their share in the structure of this fleet will be approximately $7 \%$.

The projected development of the natural gas distribution network will enable increased use of this fuel in the automotive industry, including trucks with a maximum mass of less than $3.5 \mathrm{Mg}$. It is assumed that in 2030 , about $3 \%$ of the truck fleet of this total mass will be powered by natural gas.

In the forecast discussed predicts a small $(0.1 \%$ in 2030$)$ share of electric vehicles in the structure of the trucks fleet with a maximum mass of less than $3.5 \mathrm{Mg}$. These cars would be used for example in the distribution transport in city centres.

The fleet of buses and special vehicles registered in Poland, accounts for only $1 \%$ of the motor vehicles in Poland [7].

Projected numbers of buses in Poland by the 2030 were based on projected carriage work of buses and projected average statistical productivity of the statistical vehicle. According to the forecast of the demand for transport work [2], its decline is predicted that for the years 2010-2030, although in the third decade of the century there should be certain increase, mainly due to transport by extra-urban buses.

Statistical data for the last few years confirm the declining trend in the average productivity of the carriage work of the statistical bus in the extra-urban transport. The downward trend is expected to occur still in the first half of the forecast period, then the actions for rationalizing this type of transport, are expected. These may be activities of a legal nature (legislative, control) and rationalizing the structure of the buses fleet, and other activities such as in the field of transport telematics.

Because the statute of large enterprises evolved in extra-urban public transport forces them to provide the service also on the routes of a low turnout, it must be assumed that in the face of competition primarily from the individual motorism, average annual transport work productivity of the statistical bus, after all, will not be significantly increased in the forecast period.

Decrease in the number of buses in Poland in the next 20 years will be primarily attribut-
Nadal będą rozwijały się układy dwupaliwowe (benzyna i LPG) zasilania silników samochodów ciężarowych, chociaż dynamika zmian w tym zakresie będzie niższa niż w pierwszej dekadzie XXI wieku. Przewiduje się, że w $2030 \mathrm{r}$. ich udział w strukturze przedmiotowego parku wyniesie około $7 \%$.

Zakładany rozwój sieci dystrybucji gazu ziemnego umożliwi wzrost wykorzystania tego paliwa w motoryzacji, w tym w samochodach ciężarowych o masie maksymalnej mniejszej niż 3,5 Mg. Przyjęto założenie, że w 2030 r. około $3 \%$ parku ciężarowego o tej masie całkowitej będzie zasilanych gazem ziemnym.

W przedmiotowej prognozie przewiduje się niewielki $(0,1$ $\%$ w 2030 r.) udział samochodów elektrycznych w strukturze parku samochodów ciężarowych o masie maksymalnej mniejszej niż 3,5 Mg. Samochody te znalazłyby zastosowanie np. w przewozach dystrybucyjnych w centrach miast.

Park zarejestrowanych w Polsce autobusów i samochodów specjalnych stanowi zaledwie $1 \%$ pojazdów samochodowych w Polsce [7].

Prognozowane liczby autobusów w Polsce do $2030 \mathrm{r}$. wykonano na podstawie prognozowanej pracy przewozowej autobusów i prognozowanej średniej wydajności przewozowej statystycznego pojazdu. Wg prognozy popytu na pracę przewozową [2] przewiduje się w latach 2010-2030 jej spadek, chociaż w trzeciej dekadzie wieku powinien wystąpić pewien wzrost, głównie za sprawą przewozów autobusami pozamiejskimi.

Dane statystyczne za ostatnie lata potwierdzają tendencję spadku średniej wydajności pracy przewozowej statystycznego autobusu w przewozach pozamiejskich. Występowanie tendencji spadkowej przewiduje się jeszcze w pierwszej połowie okresu prognozy, po czym należy oczekiwać działań sprzyjających racjonalizacji tego rodzaju transportu. Mogą to być działania o charakterze prawnym (legislacyjnym, kontrolnym) i działania racjonalizujące strukturę taboru autobusowego, czy inne działania np. z zakresu telematyki transportu.

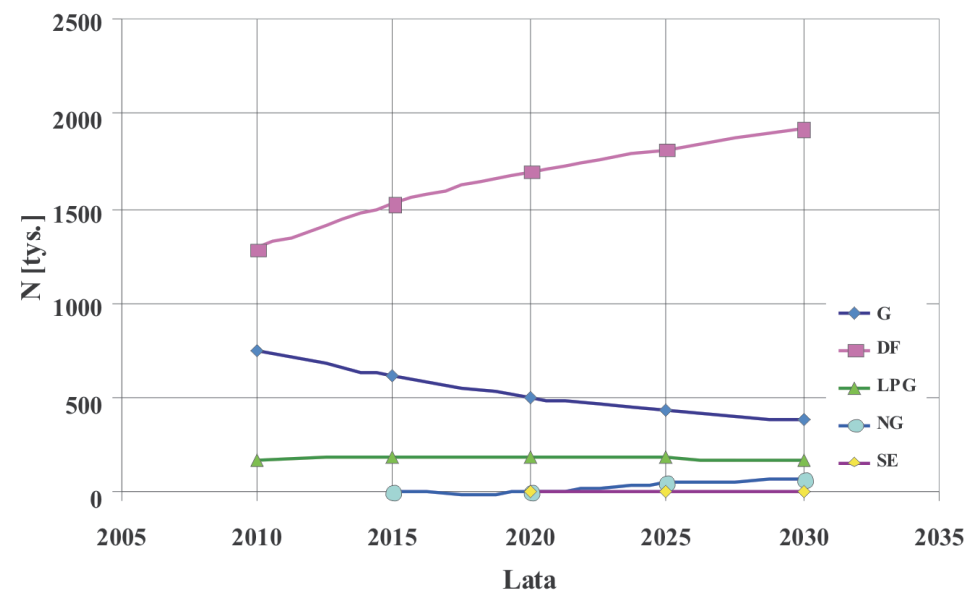

Fig. 3. Forecast of the number of trucks with a maximum mass of less than $3.5 \mathrm{Mg}$ arranged by types of energy sources: $\mathrm{G}$ - gasoline, DF - diesel fuel, LPG - liquefied petroleum gas, NG - natural gas, SE - electricity

Rys. 3. Prognoza liczb samochodów ciężarowych o masie maksymalnej mniejszej niż 3,5 Mg wg rodzajów nośników energii: $G$ - benzyna silnikowa, DF-olej napędowy, $L P G$ - skroplony gaz ropopochodny, $N G$ - gaz ziemny, SE - energia elektryczna 
able to the expected further decline in demand for transport (especially for extra-urban transport), especially between the second and third decade of the century.

The forecast for the 2030 number of buses with a maximum mass exceeding $5 \mathrm{Mg}$ in Poland should be about 74.2 thousand. Number of buses with a maximum mass of less than $5 \mathrm{Mg}$ should be about 8.2 thousand.

Projecting the number of buses with a maximum mass of less than $5 \mathrm{Mg}$ arranged by type of fuel, it was assumed (as in the case of trucks forecast) that in 2030 about $75 \%$ buses of this group will be equipped with engines powered by diesel fuel, $15 \%$ - gasoline, $7 \%$ - LPG and $3 \%$ natural gas. According to the assumptions, in 2030 about 6.2 thousand buses with a maximum mass of less than $5 \mathrm{Mg}$ should run on the diesel fuel.

While projecting the number of special vehicles in Poland until the 2030, a simplified assumption $t$ was adopted, that during the forecast period, share of special vehicles in the total number of trucks will constitute about $4.5 \%$. This assumption is based on the analysis of the formation this share in the years 2000, 2005 and 2010. Number of special vehicles in 2030 should amount to about 150 thousand, including about 110 thousand with a maximum mass of more than $3.5 \mathrm{Mg}$.

\section{Estimation of the average annual mileages of statistical vehicles registered in Poland by the 2030}

Up till 2010, the estimates of the average annual mileages of the car fleet registered in Poland, arranged by type, specified categories and fuel types were performed at the Motor Transport Institute in the course of the registering pollutants emissions from road transport means [12]. The studies conducted by ITS consisted of (generally speaking) accounting for consumption of liquefied fuels and LPG gas in the transport and other sectors of the economy.

The average annual mileages of the statistical cars in the selected years of the forecast were calculated taking into account current forecasts and analyzes concerning:

a) volume of transport work [2],

b) total number of vehicles $[3,7]$,

c) average values of technical and operational indicators characterizing the operation of road transport (e.g. number of persons in the car, fleet utilization indicator, etc).

The average annual vehicles mileages arranged by the type of energy sources in the forecast years was estimated by experts, using current awareness and trends in this respect [12] and with the assumptions concerning formation of technical and operational indicators for the fleet performance in the forecast period.

The relatively high growth rate of the number of passenger cars in Poland in 2001-2010 (over 160 \%) did not unequivocally affect the increase or decrease of the average annual mileages of passenger cars in our country. The calculations, when confronted with the projections of the Polish population mobility and transport work forecasts expected to be conducted with passenger cars [2], show that
Ponieważ statut dużych przedsiębiorstw realizujących pozamiejskie przewozy publiczne zmusza je do zapewniania również obsługi na liniach o niewielkiej frekwencji, należy przyjąć, że wobec konkurencji przede wszystkim ze strony motoryzacji indywidualnej, średnia roczna wydajność pracy przewozowej statystycznego autobusu, mimo wszystko, nie ulegnie znaczącemu wzrostowi w okresie objętym prognozą.

Spadek liczby autobusów w Polsce w perspektywie 20 lat będzie wynikać przede wszystkim z przewidywanego dalszego spadku popytu na przewozy (szczególnie na przewozy pozamiejskie) zwłaszcza na przełomie drugiej i trzeciej dekady wieku.

Prognozowana na rok 2030 liczba autobusów o masie maksymalnej większej niż $5 \mathrm{Mg}$ w Polsce powinna wynieść około 74,2 tys. szt. Liczba autobusów o masie maksymalnej mniejszej niż do $5 \mathrm{Mg}$ powinna wynieść około 8,2 tys. szt.

Prognozując liczby autobusów o masie maksymalnej mniejszej niż $5 \mathrm{Mg}$ wg rodzajów paliw, przyjęto (podobnie jak w przypadku prognozy samochodów ciężarowych), że w 2030 r. około $75 \%$ autobusów tej grupy wyposażonych będzie w silniki zasilane olejem napędowym, $15 \%$ - benzyną, 7 \% - gazem LPG i $3 \%$ gazem ziemnym. W myśl przyjętych założeń, w 2030 r. około 6,2 tys. autobusów o masie maksymalnej mniejszej niż $5 \mathrm{Mg}$ powinno być zasilanych olejem napędowym.

Prognozując liczebność samochodów specjalnych w Polsce do 2030 r. przyjęto uproszczone założenie, że w latach prognozy udział samochodów specjalnych w ogólnej liczbie samochodów ciężarowych stanowił będzie około 4,5 \%. Założenie to wynika z analizy kształtowania się tego udziału w latach 2000, 2005 i 2010. Liczba samochodów specjalnych w 2030 r. powinna wynieść około 150 tys. szt., w tym około 110 tys. szt. o masie maksymalnej większej niż 3,5 Mg.

\section{Oszacowanie średnich rocznych przebiegów statystycznych pojazdów zarejestrowanych w Polsce do 2030 r.}

Do 2010 r. oszacowania średnich rocznych przebiegów parku samochodowego zarejestrowanego w Polsce wg rodzajów, wyspecyfikowanych kategorii i wg rodzajów paliw były wykonywane w Instytucie Transportu Samochodowego przy okazji prac inwentaryzacyjnych emisji zanieczyszczeń ze środków transportu samochodowego [12]. Badania ITS polegały (ogólnie mówiąc) na bilansowaniu zużycia paliw ciekłych oraz paliwa gazowego LPG w transporcie i w innych działach gospodarki.

Średnie roczne przebiegi statystycznych samochodów w wybranych latach prognozy obliczono uwzględniając aktualne prognozy i analizy dotyczące:

a) wielkości pracy przewozowej [2],

b) ogólnych liczb samochodów [3, 7],

c) średnich wartości wskaźników techniczno-eksploatacyjnych charakteryzujących pracę transportu samochodowego (np. liczba osób w samochodzie, wskaźnik wykorzystania taboru itp).

Średnie roczne przebiegi pojazdów wg rodzajów nośników energii dla lat prognozy oszacowano ekspercko, 


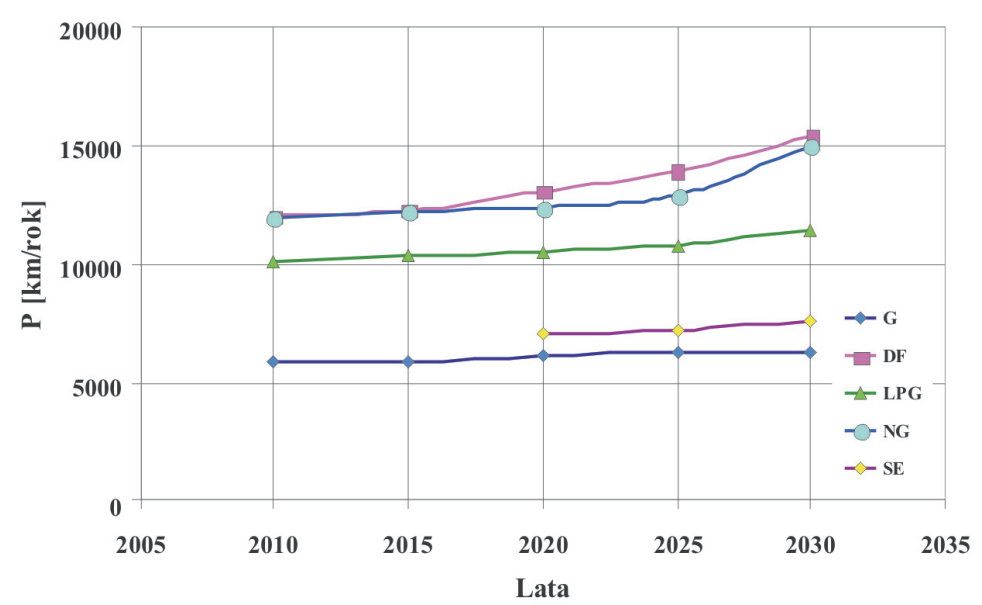

Fig. 4. Forecast of the average annual car mileages by types of energy sources: $\mathrm{G}$ - gasoline, DF - diesel fuel, LPG - liquefied petroleum gas, NG - natural gas, SE - electricity Rys. 4. Prognoza średnich rocznych przebiegów samochodów osobowych wg rodzajów nośników energii: $G$ - benzyna silnikowa, $D F$ - olej napędowy, $L P G$-skroplony gaz ropopochodny, $N G$ - gaz ziemny, $S E$ - energia elektryczna

the average annual car mileages of statistical cars in Poland will increase (Fig. 4).

In the period up to 2030 among passenger cars registered in Poland, the largest average annual mileages should reach cars with engines fuelled by diesel and natural gas. It is expected that users of cars with petrol engines will not be heavily exploiting their cars, as do it, and probably will still be doing it, the owners of cars with diesel engines and engines on gaseous fuels.

In the case of electric vehicles they are expected to be operating in the areas of agglomerations, hence their small daily and annual mileages.

It is estimated that the average annual mileage of a statistical truck with a maximum mass of less than $3.5 \mathrm{Mg}$ in 2030 will be about 15,800 km (Fig. 5).

According to the projections, amongst trucks with a maximum mass of less than $3.5 \mathrm{Mg}$, by the 2030 the highest average mileages per year will be reached by cars with engines powered with diesel and gaseous fuels.

The average annual mileage of a statistical truck with a maximum mass of more than 3.5 $\mathrm{Mg}$ by the year 2030 will be approximately $31,900 \mathrm{~km}$ (Fig. 6).

The average annual mileages of a statistical bus with a maximum mass exceeding 5 Mg estimated, for the years 2000-2010, were characterized by a lack of stability, but certain declining trend can be noticed [12]. The predicted, average annual mileage of a statistical bus with a maximum mass exceeding $5 \mathrm{Mg}$ in 2030, with the adopted assumptions, will be about 32,000 km/year (Fig. 7).

Special-purpose vehicles with a maximum mass of more than $3.5 \mathrm{Mg}$ are not used to transport goods or people, so their function of wykorzystując m.in. dotychczasowe rozpoznanie i występujące tendencje w przedmiotowym zakresie [12] oraz przyjmując założenia dotyczące kształtowania się wskaźników techniczno-eksploatacyjnych pracy taboru w latach prognozy.

Stosunkowo duża dynamika wzrostu liczby samochodów osobowych w Polsce w latach 2001-2010 (przeszło 160\%) nie wpłynęła jednoznacznie na wzrost lub spadek średnich rocznych przebiegów samochodów osobowych w naszym kraju. Wykonane obliczenia, wobec prognoz mobilności mieszkańców Polski i prognoz pracy przewozowej przewidywanej do wykonania samochodami osobowymi [2], wskazują, że średnie roczne przebiegi statystycznych samochodów w Polsce będą wzrastały (rys. 4).

W okresie do 2030 r. wśród samochodów osobowych zarejestrowanych w Polsce największe średnie roczne przebiegi powinny osiągać samochody z silnikami zasilanymi olejem napędowym oraz samochody na gaz ziemny. Przewiduje się, że użytkownicy samochodów z silnikami benzynowymi w większości nie będą intensywnie eksploatowali swoich samochodów, jak czynią to i prawdopodobnie będą czynili właściciele samochodów z silnikami na olej napędowy i z silnikami na paliwa gazowe.

W przypadku samochodów elektrycznych przewiduje się ich eksploatację na obszarach aglomeracji, a przez to ich niewielkie przebiegi dobowe i roczne.

Szacuje się, że średni roczny przebieg statystycznego samochodu ciężarowego o masie maksymalnej mniejszej niż 3,5 Mg w 2030 r. wyniesie około 15800 km (rys. 5).

Wg przewidywań, wśród samochodów ciężarowych o masie maksymalnej mniejszej niż 3,5 Mg, do 2030 r. naj-

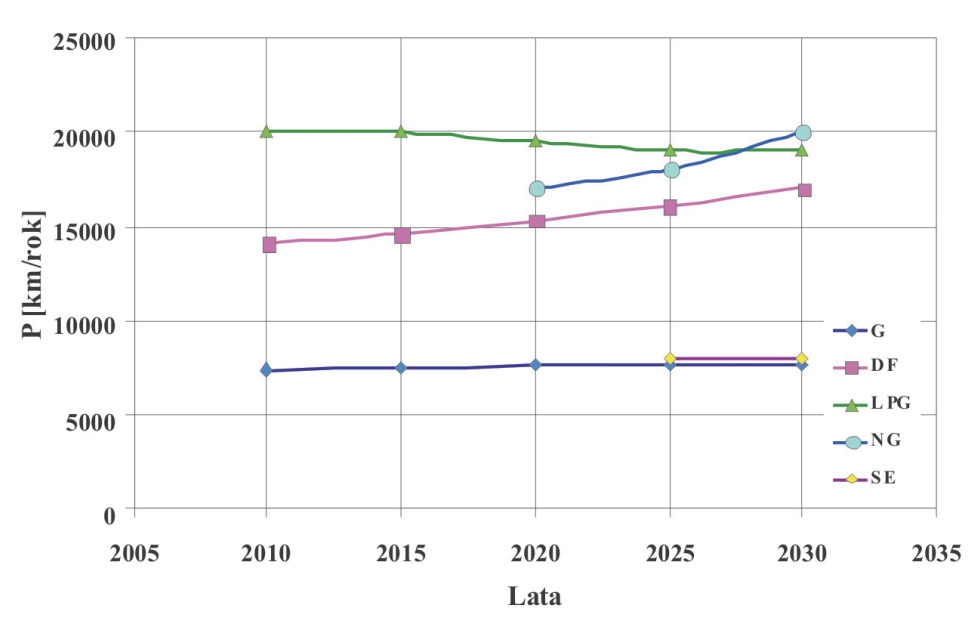

Fig. 5. Forecast of the average annual truck mileages with a maximum mass of less than $3.5 \mathrm{Mg}$ arranged by types of energy: $\mathrm{G}$ - gasoline, DF - diesel fuel, LPG - liquefied petroleum gas, NG - natural gas, SE - electricity

Rys. 5. Prognoza średnich rocznych przebiegów samochodów ciężarowych o masie maksymalnej mniejszej niż 3,5 Mg wg rodzajów nośników energii: $G$ - benzyna silnikowa, $D F$ - olej napędowy, LPG - skroplony gaz ropopochodny, NG - gaz ziemny, SE-energia elektryczna 


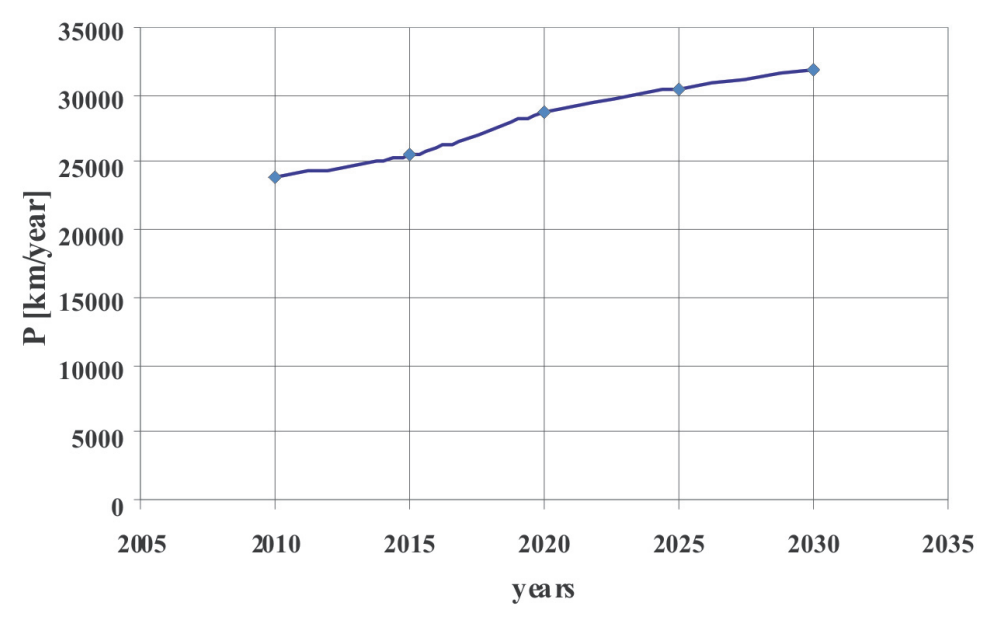

Fig. 6. Forecast of the average annual mileages of trucks with a maximum mass of more than $3.5 \mathrm{Mg}$

Rys. 6. Prognoza średnich rocznych przebiegów samochodów ciężarowych o masie maksymalnej większej niż 3,5 Mg

driving on the roads is not the prime scope of the use of these vehicles. Special cars trips (and therefore fuel consumed for this purpose) are only part of their job. The issues of the specifics of fuel consumption by this car fleet along the road trips and fuel consumption issues while operating at a standstill are currently the subject of discussion among experts at the European Commission dealing with car-transport activity monitoring.

In the case of special vehicles with a maximum mass of more than $3.5 \mathrm{Mg}$ in Poland there is no statistical data on their average annual mileages and no special research has been carried out in this field. Therefore, in these estimates were used expert estimates, assuming that these vehicles are driving locally, hence the average annual mileage of such statistical vehicle is at the level of (10-15) \% of the average annual mileage of a statistical truck with a maxi-

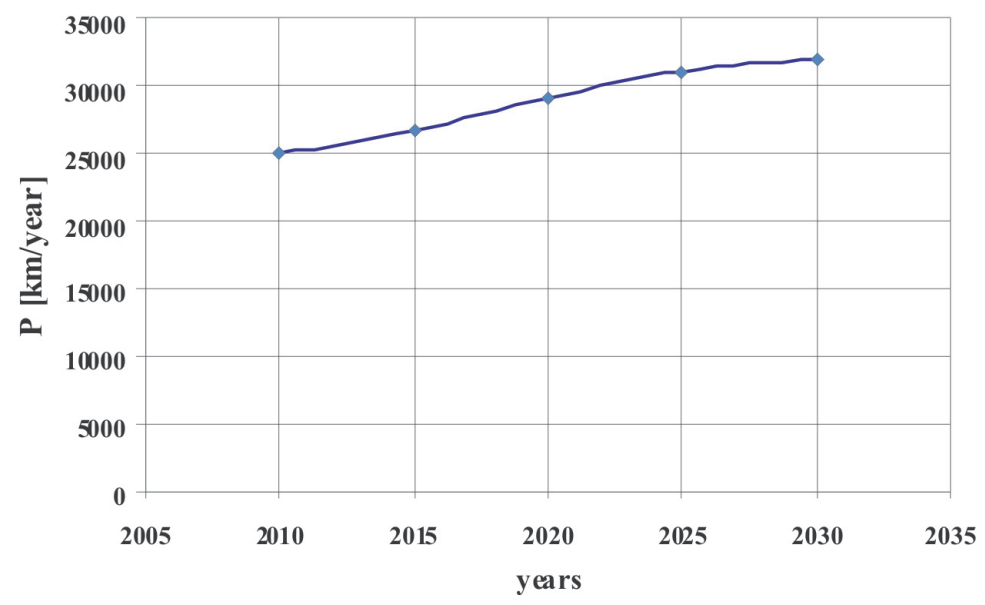

Fig. 7. Forecast of the average annual bus mileages with a maximum mass exceeding $5 \mathrm{Mg}$

Rys. 7. Prognoza średnich rocznych przebiegów autobusów o masie maksymalnej większej niż $5 \mathrm{Mg}$ większe średnie przebiegi w roku będą osiągały samochody z silnikami zasilanymi olejem napędowym i paliwami gazowymi.

Średni roczny przebieg statystycznego pojazdu ciężarowego masie całkowitej większej niż 3,5 Mg w perspektywie 2030 r. dla roku 2030 wyniesie około 31900 km (rys. 6).

Oszacowane dla lat 2000-2010 średnie roczne przebiegi statystycznego autobusu o masie maksymalnej większej niż $5 \mathrm{Mg}$ charakteryzowały się brakiem stabilności, jednak można zauważyć pewną tendencję ich spadku [12]. Prognozowany, przy przyjętych założeniach średni roczny przebieg statystycznego autobusu o masie maksymalnej większej niż $5 \mathrm{Mg} \mathrm{w}$ 2030 r. wyniesie około $32000 \mathrm{~km} /$ rok (rys. 7).

Samochody specjalne o masie maksymalnej większej niż 3,5 Mg nie służą do przewozu ładunków ani osób, stąd ich funkcja przemieszczania się po drogach nie stanowi zasadniczego zakresu wykorzystania tych pojazdów. Przejazdy samochodów specjalnych (i w związku z tym zużywane do tego celu paliwo) stanowi zaledwie część ich pracy. Kwestie specyfikacji zużycia paliw przez ten park samochodowy w zakresie przejazdów po drogach i kwestie zużycia paliw w czasie pracy na postoju, są aktualnie przedmiotem rozważań wśród specjalistów na szczeblu KE zajmujących się problematyką monitorowania aktywności transportu samochodowego.

W przypadku samochodów specjalnych o masie maksymalnej większej niż 3,5 Mg brak jest w Polsce danych statystycznych na temat ich średnich rocznych przebiegów i nie prowadzono w tym zakresie specjalnych badań. Dlatego w przedmiotowych szacunkach posłużono się szacunkami eksperckimi, wychodząc z założenia, że pojazdy te przemieszczają się lokalnie, stąd średni roczny przebieg przedmiotowego statystycznego pojazdu kształtuje się na poziomie (10-15) \% średniego rocznego przebiegu statystycznego samochodu ciężarowego o masie maksymalnej większej niż 3,5 Mg w 2010 r. i brak jest przesłanek, aby te średnie przebiegi ulegały zmianom w okresie prognozy.

\section{Prognoza średniego eksploatacyjnego zużycia nośników energii}

W zakresie szacowania średniego eksploatacyjnego zużycia benzyny i oleju napędowego (na $100 \mathrm{~km}$ przebiegu pojazdów) w Polsce, bazowano na oprogramowaniu INFRAS AG [8] oraz modelu opóźnienia rozwoju motoryzacji w Polsce w stosunku do stanu w Europie Zachodniej, ekstrapolowanym do 2030 r. [5]. Proporcje zmian średniego eksploatacyjnego zużycia paliw wynikające z modelu INFRAS AG w latach 2010-2020 wykorzystano do 
mum mass of more than $3.5 \mathrm{Mg}$ in 2010 and there is no evidence that these average courses would change in the forecast period.

\section{Forecast of the average operational energy sources consumption}

In terms of estimating average operational consumption of petrol and diesel (per $100 \mathrm{~km}$ of vehicles mileages) in Poland, it was based on INFRAS AG [8] software and the model of delay of the automotive industry development in Poland in relation to the state in Western Europe, extrapolated to 2030 [5]. The proportions of the average changes of operational fuel consumption resulting from INFRAS AG model in the years 2010-2020 were used to estimate the corresponding values for the years 2025, 2030, accepting as a starting figures the average operational fuel consumption (petrol, diesel fuel) in Poland in 2010, which is volumes were estimated at ITS [12].

The average operational LPG consumption by passenger cars was assumed by experts on the condition that the average operational consumption of LPG will be approximately $25 \%$ higher than the average projected operational petrol consumption. This ratio is due to the fact that most cars with a large volume engines (and thus a relatively high average operational consumption of petrol) are and will be adjusted in future years to run on gaseous fuels, including LPG.

In the case of the average operational consumption of natural gas, the following converting coefficient was adopted in relation to the petrol consumption: $1.1 \mathrm{Nm}^{3} \mathrm{CNG}$ is an equivalent $1.0 \mathrm{dm}^{3}$ of gasoline.

\section{Forecast of energy sources consumption by the Polish fleet of cars for the $\mathbf{2 0 3 0}$}

The projection assumptions adopted and the calculations made on their basis indicate that the consumption of gasoline by passenger cars will continue to increase by 2025 reaching a level of about $3,700 \mathrm{Gg}$, only to be reduced in the 2030 to about 3,570 Gg (Fig. 8).

Similarly, the consumption of diesel oil by passenger cars is expected to increase to about $4,350 \mathrm{Gg}$, and then a slight decline to about $4,320 \mathrm{Gg}$ in 2030. In the case of consumption of LPG by passenger cars one ought to expect an increase in consumption to about 1,800 $\mathrm{Gg}$ in the years 2025 and 2030. Natural gas consumption by passenger cars in 2030 should amount to about $400 \mathrm{Gg}$, and electrical power consumption of about $39,000 \mathrm{~kW} \cdot \mathrm{h}$.

Gasoline consumption by cars with a maximum mass of less than $3.5 \mathrm{Mg}$ (other than passenger cars) will drop, reaching about 183 Gg in 2030 (Fig. 9).

Consumption of diesel fuel by the said group of vehicles will grow to about $1,910 \mathrm{Gg}$ in 2025, and in 2030 will be about $1,890 \mathrm{Gg}$. LPG consumption will drop, and by 2030 will be about $190 \mathrm{Gg}$. It is expected that the con- oszacowania odpowiednich wartości dla lat 2025, 2030, przyjmując za wielkości wyjściowe średnie eksploatacyjne zużycie paliw (benzyny, oleju napędowego) w Polsce w 2010 r., które to wielkości zostały oszacowane w ITS dla roku 2010 [12].

Średnie eksploatacyjne zużycie paliwa LPG przez samochody osobowe przyjęto ekspercko przy założeniu, że średnie eksploatacyjne zużycie LPG będzie o około $25 \%$ większe niż prognozowane średnie eksploatacyjne zużycie benzyny. Proporcja ta wynika z faktów, że przeważnie samochody z silnikami o dużej objętości skokowej (a zatem o stosunkowo dużym średnim eksploatacyjnym zużyciu benzyny) są i będą w przyszłych latach dostosowywane do zasilania paliwami gazowymi, w tym LPG.

W przypadku średniego eksploatacyjnego zużycia gazu ziemnego przyjęto następujący przelicznik w stosunku do zużycia benzyny: $1,1 \mathrm{Nm}^{3} \mathrm{CNG}$ odpowiada $1,0 \mathrm{dm}^{3}$ benzyny.

\section{Prognoza zużycia nośników energii przez polski park samochodowy w perspektywie $2030 \mathrm{r}$.}

Przyjęte założenia prognostyczne i wykonane na ich podstawie obliczenia wskazują, że zużycie benzyn przez samochody osobowe będzie się zwiększało do 2025 r. osiągając poziom około $3700 \mathrm{Gg}$, aby w $2030 \mathrm{r}$. ulec zmniejszeniu do około 3570 Gg (rys. 8).

Podobnie przewiduje się wzrost zużycia oleju napędowego przez samochody osobowe do około $4350 \mathrm{Gg}$, a następnie niewielki spadek do około $4320 \mathrm{Gg}$ w 2030 r. W przypadku zużycia skroplonego gazu ropopochodnego przez samochody osobowe należy spodziewać się wzrostu zużycia do około $1800 \mathrm{Gg}$ w latach 2025 i 2030. Zużycie gazu ziemnego przez samochody osobowe w 2030 r. powinno wynieść około 400 Gg, a zużycie energii elektrycznej około $39000 \mathrm{~kW} \cdot \mathrm{h}$.

Zużycie benzyn przez samochody o masie maksymalnej mniejszej niż 3,5 Mg (inne niż samochody osobowe) będzie spadało, osiągając poziom około $183 \mathrm{Gg} \mathrm{w} 2030 \mathrm{r}$. (rys. 9).

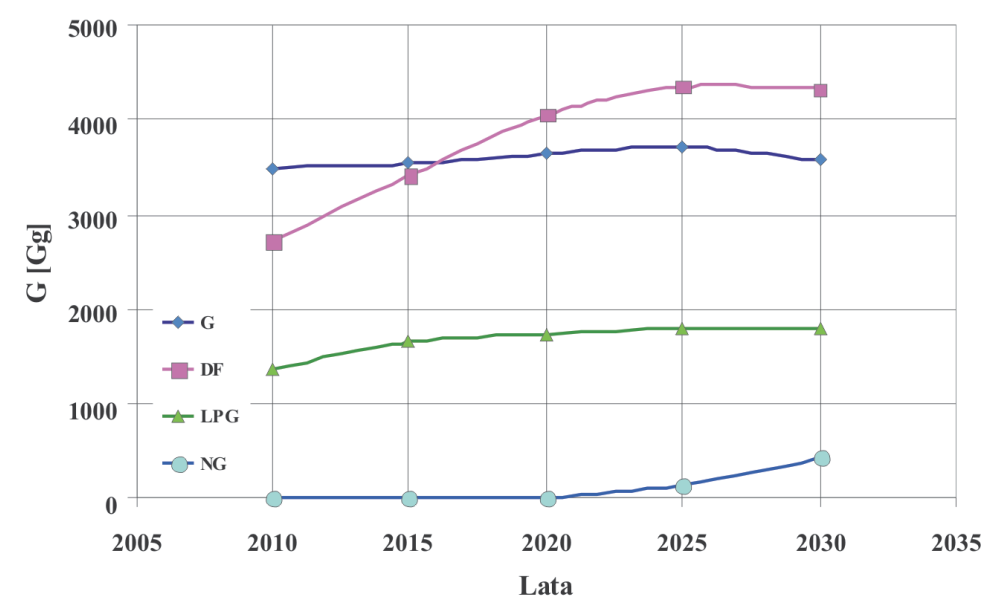

Fig. 8. Consumption projection of gasoline - G, diesel fuel - DF, LPG and natural gas NG by passenger cars

Rys. 8. Prognoza zużycia benzyny - G, oleju napędowego - DF, LPG i gazu ziemnego$N G$ przez samochody osobowe 
sumption of natural gas in the form of $\mathrm{CNG}$ or $\mathrm{LNG}$ in 2030 will reached about $87.4 \mathrm{Gg}$ and electricity consumption will reach $6,540 \mathrm{~kW} \cdot \mathrm{h}$.

The projection assumptions adopted and the calculations made on their basis indicate that the consumption of diesel fuel by cars with a maximum mass of more than $3.5 \mathrm{Mg}$ will increase reaching a level of about 6,504 Gg in 2030 (Fig. 10).

Projected gasoline demand by the Polish car fleet in 2030 will be about $3,760 \mathrm{Gg}$ and will be comparable to the consumption of gasoline in 2010 (Fig. 11).

The estimated diesel fuel demand will be about $12,710 \mathrm{Gg}$ and will be about $44 \%$ higher than the consumption in 2010.

Projected demand for LPG by the fleet of cars will be about 2,000 Gg (an increase of approximately $24 \%$ compared to 2010 ).

The demand of natural gas to power the car engines in 2030 is estimated at about $480 \mathrm{Gg}$, and

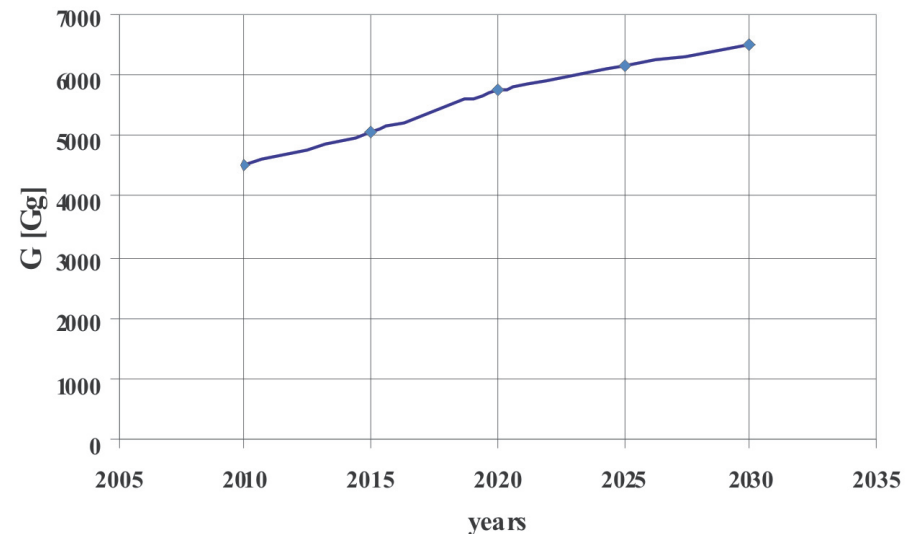

Fig. 10. Consumption forecast of diesel fuel by cars with a maximum mass of more than $3.5 \mathrm{Mg}$

Rys. 10. Prognoza zużycia oleju napędowego przez samochody o masie maksymalnej większej niż 3,5 Mg

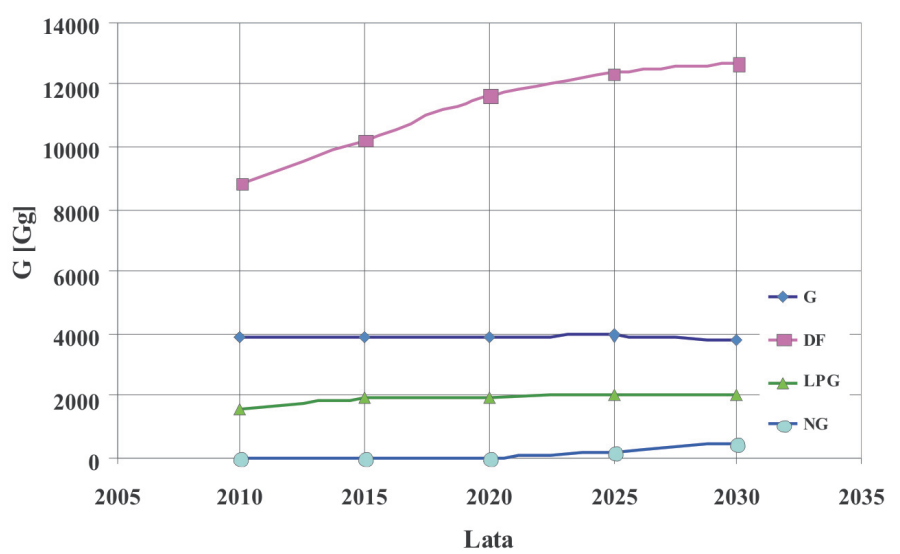

Fig. 11. Forecast of energy sources consumption: $\mathrm{G}$ - gasoline, DF - diesel fuel, $\mathrm{LPG}$ - liquefied petroleum gas, $\mathrm{NG}$ - natural gas

Rys. 11. Prognoza zużycia nośników energii: $G$ - benzyna silnikowa, DF-olej napędowy, LPG - skroplony gaz ropopochodny, NG - gaz ziemny
Zużycie oleju napędowego przez przedmiotową grupę pojazdów będzie wzrastało do około $1910 \mathrm{Gg} \mathrm{w}$ 2025r., a w 2030 r. wyniesie około 1890 Gg. Zużycie gazu LPG będzie spadało i w 2030 r. wyniesie około 190 Gg. Przewiduje się, że zużycie gazu ziemnego w postaci CNG lub LNG osiągnie w 2030 r. około $87,4 \mathrm{Gg}$, a zużycie energii elektrycznej wyniesie $6540 \mathrm{~kW} \cdot \mathrm{h}$

Przyjęte założenia prognostyczne i wykonane na ich podstawie obliczenia wskazują, że zużycie oleju napędowego przez samochody o masie maksymalnej większej niż 3,5 Mg będzie rosło osiągając poziom około $6504 \mathrm{Gg}$ w 2030 r. (rys. 10).

Przewidywane zapotrzebowanie benzyny przez polski park samochodowy w $2030 \mathrm{r}$. wyniesie około $3760 \mathrm{Gg}$ i będzie porównywalne ze zużyciem benzyny w 2010 r. (rys. 11).

Szacowane zapotrzebowanie oleju napędowego wyniesie około $12710 \mathrm{Gg}$ i będzie o $44 \%$ większe od zużycia w $2010 \mathrm{r}$.

Prognozowane zapotrzebowanie skroplonego gazu ropopochodnego przez park samochodowy wyniesie około $2000 \mathrm{Gg}$ (wzrost o około $24 \%$ w porównaniu z 2010 r.).

Zapotrzebowanie gazu ziemnego do zasilania silników samochodowych w 2030 r. szacuje się na około $480 \mathrm{Gg}$, a zapotrzebowanie energii elektrycznej do ładowania akumulatorów samochodów elektrycznych wyniesie w $2030 \mathrm{r}$. około $45 \mathrm{MW} \cdot \mathrm{h}$.

\section{Zakończenie}

Cechą przewidywań prognostycznych jest to, że bazują jedynie na prawdopodobnym scenariuszu zdarzeń warunkujących rozwój danego zjawiska. Stąd, wobec zmieniających się z czasem różnorodnych czynnikach determinujących przedmiot prognozy, celowa jest jej okresowa aktualizacja. 
the demand of electricity for charging electric cars in 2030 will be approximately $45 \mathrm{MW} \cdot \mathrm{h}$.

\section{Conclusion}

Prognostic prediction feature is that it is based only upon the likely scenario of events influencing the development of a given phenomenon. Hence, with various factors determining the subject of predictions, changing with the time the, the appropriate is a periodical update. A good example is the demand forecasts for transport, commissioned by MTBiGM at the University of Gdansk [2], whose several versions were developed in the recent years.

This is why such demand forecast for energy sources by the Polish car fleet should be updated in the coming years. Document for the revision of the forecasts of demand for energy sources is a draft regulation, being prepared by the Council of Ministers, on the scope of information that should be included in the projections of the activity changes for the individual sectors of the economy [9]. Regulation being represents implementation of the authorization contained in Article. Paragraph 9.3 of the Act of 17 July 2009 on the management system of greenhouse gases emissions and other substances. These documents testify of the need to develop next versions of the expected demand for energy sources every 5 years.
Dobrym przykładem są prognozy popytu na przewozy, wykonywane na zapotrzebowanie MTBiGM na Uniwersytecie Gdańskim [2], których w ostatnich latach opracowano kilka wersji.

Dlatego m.in. prognoza popytu na nośniki energii przez polski park samochodowy powinna być w kolejnych latach aktualizowana. Dokumentem służącym sprawie aktualizacji prognoz popytu na nośniki energii jest przygotowywany przez Radę Ministrów projekt rozporządzenia w sprawie zakresu informacji, jakie powinny być zawarte w prognozach zmian aktywności dla poszczególnych sektorów gospodarki [9]. Przygotowywane rozporządzenie stanowi wykonanie upoważnienia zawartego $\mathrm{w}$ art. 9 ust. 3 ustawy z dnia 17 lipca 2009 r. o systemie zarządzania emisjami gazów cieplarnianych i innych substancji. Dokumenty te stanowią o potrzebie opracowywania kolejnych wersji prognoz popytu na nośniki energii co 5 lat.

\section{Bibliography/Literatura}

[1] Becker T.A., Sidhu I., Tenderich B.: Electric vehicles in the United States. A New model with forecasts to 2030. Center for Entrepreneurship \& Technology (CET). Technical Brief Number 2009.1.v.2.0. Revision Date: August 24, 2009.

[2] Burnewicz J.: Prognozy popytu na transport w Polsce do roku 2020 i 2030 (rok bazowy 2010). Załącznik nr 2 do „Strategii rozwoju transportu”. Ministerstwo Infrastruktury. 2012.

[3] Burnewicz J.: Strategia rozwoju transportu Polski do 2020 roku (z perspektywą do 2030 roku). Europejski Kongres Finansowy. Sopot 2012.

[4] Balke I., Balke M.: Badanie struktury ilościowej parku samochodowego w Polsce $\mathrm{z}$ uwzględnieniem marek i wieku wybranych rodzajów pojazdów według stanu na koniec 2009 roku. Praca ITS nr 6002/ZBE. Warszawa 2011.

[5] Chłopek Z.: Modelowanie procesów emisji spalin w warunkach eksploatacji trakcyjnej silników spalinowych. Prace Naukowe. Seria „Mechanika” z. 173. Oficyna Wydawnicza Politechniki Warszawskiej. Warszawa 1999.

[6] Chłopek Z.: Research on energy consumption by an electrically driven automotive vehicle in simulated urban conditions.
Eksploatacja i Niezawodnosc - Maintenance and Reliability 2013; 15 (1). 75-82.

[7] GUS: Transport - wyniki działalności w $2011 \mathrm{r}$.

[8] INFRAS AG: Handbuch für Emissionsfaktoren des Strassenverkehrs. Version 3.1. Bern 2010.

[9] Projekt rozporządzenia Rady Ministrów w sprawie zakresu informacji, jakie powinny być zawarte w prognozach zmian aktywności dla poszczególnych sektorów gospodarki z dnia 23 grudnia $2011 \mathrm{r}$.

[10] Rozporządzenie Ministra Infrastruktury z dnia 24 października 2005 r. w sprawie homologacji typu pojazdów samochodowych i przyczep.

[11] Waśkiewicz J., Chłopek Z., Pawlak P.: Ekspercka prognoza popytu na nośniki energii przez park samochodowy w Polsce w perspektywie 2030 r. Praca ITS nr 6243/ZBE. 2011.

[12] Waśkiewicz J., Radzimirski ST., Taubert S.: Opracowanie metodologii prognozowania zmian aktywności sektora transportu drogowego (w kontekście ustawy o systemie zarządzania emisjami gazów cieplarnianych i innych substancji). Praca ITS nr 7101/ZBE wykonana dla MTBiGM. 2011.
Prof. Zdzisław Chłopek, DSc., DEng. - Professor, Motor Transport Institute, Warsaw.

Prof. dr hab. inż. Zdzistaw Chlopek-Instytut Transportu Samochodowego w Warszawie. e-mail:moriarty@o2.pl

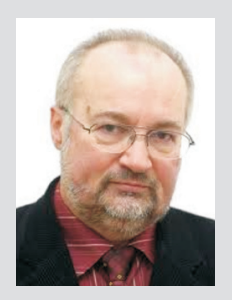

Jerzy Waśkiewicz, DEng. - Head of Economic Research Department inMotor Transport Institute in Warsaw.

Dr inż. Jerzy Waśkiewicz - kierownik Zaktadu Badań Ekonomicznych w Instytucie Transportu Samochodowego $w$ Warszawie.

e-mail:jerzy.waskiewicz@its.waw.pl 